\title{
VIABLE HEALTH FUNDING IN TIME OF DEMOGRAPHIC AGEING
}

\author{
Marija Trpkova-Nestorovska \\ Faculty of Economics - Skopje, Ss Cyril and Methodius University \\ marija.trpkova-nestorovska@eccf.ukim.edu.mk
}

\begin{abstract}
In the past several decades a new challenge has arisen, and it refers to the rapid demographic ageing of the population in developed and developing countries, quite opposite to the previous understanding of overpopulated planet. Increase in the older population brings its implications to different segments of the society, and the national health system and its funding is one of them. This paper tends to analyze if there is a relationship between the government health expenditure and the increase in the older population in fourteen countries from the European Union that are experiencing most intense process of demographic ageing. Also, other possible determinants of the health expenditures are included, such as government social spending, gross domestic product per capita and dummy variable to estimate the effect of the global recession onto the health expenditure.
\end{abstract}

Keywords: Demographic ageing, Health expenditure, Panel regression model

JEL classification: $J 11, I 18, C 33$

http://hdl.handle.net/20.500.12188/15930

http://doi.org/10.47063/EBTSF.2021.0017 